\title{
Virtual or face to face classes: Ecuadorian university students' perceptions during the pandemic
}

\author{
Julia Sevy-Biloon \\ Universidad Nacional de educacion (UNAE), 54WH+6H Chuquipata Centro, Ecuador \\ julia.sevy@unae.edu.ec
}

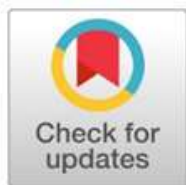

\section{ARTICLE INFO}

Article history

Received 07 April 2021

Revised 16 April 2021

Accepted 21 April 2021

Keywords

ELT

EFL

virtual learning and teaching

face-to-face learning and teaching

E-learning

\begin{abstract}
Due to the pandemic, classes have moved online for 2020-2021, and a return to face-to-face classes in the National University of Education (UNAE) in Ecuador is unknown. Students studying in the undergraduate program to be English language teachers are slowly adapting to this new form of E-learning, and some have found that they prefer online classes, while many are waiting for the day they return to classes. The objective of this study is to look at the pros and cons given by 69 students discussing why taking classes virtually or face to face is a better option for EFL and being an ELT professional in these turbulent times. Some prefer online learning for various reasons such as safety, comfort, economic reasons, and having more time in general. Some find Elearning difficult and want to return to synchronous classes because they feel there is little interaction between classmates and teachers, they cannot practice English authentically, cannot get clarification from the teacher, have a hard time concentrating online, and there are constant internet connection issues. In conclusion, this information has great importance for teachers today who are struggling to teach in this new medium and teach to the needs of their students to aid in their planning and will contribute to future teachers who will teach online.
\end{abstract}

This is an open-access article under the CC-BY-SA license.

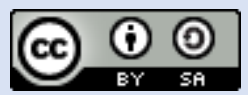

How to Cite: Sevy-Biloon, J. (2021). Virtual or face to face classes: Ecuadorian university students' perceptions during the pandemic. English Language Teaching Educational Journal, 4(1), 15-24. doi.org/10.12928/eltej.v4i1.3935

\section{Introduction}

Since the pandemic started, teachers have had to reevaluate and reformat how classes are taught and delivered. Allo (2020) and Raveendran (2021) explains how around the world, schools have closed and are no longer providing face-to-face classes. This is no different in Ecuador. Though students and teachers alike are still being expected to complete the same tasks but in a new way. Teachers still must teach, and students still must learn but through a new medium of E-learning. Cabero (2006) explains how E-learning is a new form of distance education that allows the teachers to use innovative technologies to create a more interactive class while the teacher and students are in different geographic places.

In the national university of education (UNAE) in Ecuador, this has proven to be almost impossible since teachers and students alike are struggling in the new medium of E-learning where classes were previously designed to be face to face. Allo (2020) makes it clear that students have various opinions about E-learning and their new reality, and it is important to understand these perceptions to improve online learning environments. This paper looks into students' perceptions and opinions of staying 
home and taking classes online through an E-learning format. It looks at what students think are the pros and cons of this new learning form due to the COVID-19 pandemic and how teachers are attempting to adapt. Akande and Samson (2009) discuss how perceptions can help understand a person's motivation and how they will react to different situations. In terms of the classroom and this new environment, it is important to understand what students think to help teachers plan for the future. Allo (2020) describes how teachers are adapting to this new reality by giving lectures, using various online learning tools, online forums, applications for virtual assignments, and E-classrooms to continue student education and how these adaptions affect their students' abilities to learn and their motivation. Layali and Al-Shlowiy (2020) explain how focusing on students' perceptions to understand this new reality can give new insight into how the COVID-19 pandemic has changed the face of education and how to move forward.

At the beginning of the pandemic, teachers had little time to prepare for online classes and had to learn how to teach through video conference applications. They also had to learn how to base their classes around their virtual classroom. Agung, Surtikanti and Quinones (2020) describe how the initial problem of E-learning was lack of or unstable internet connection creating a situation where everyone had to quickly adapt and find solutions to continue education during the pandemic. Many students were initially faced with the basic problem of not having internet access in their homes. In Ecuador (la educacion en Ecuador, 2020), 4.5 million students were affected when schools closed in March of 2020 due to the pandemic. According to an article in the newspaper El Pais by Constante (2020, June 16), over $70 \%$ of students do not have internet access in their homes or the necessary technology for them to successfully study. These sources show how this occurrence is like the rest of the world.

In UNAE, EFL students and teachers have been adapting to this new medium for the last year. Teachers have had to adapt and learn new forms of teaching and assessment, teach longer hours, take courses about technological tools to aid in teaching and support the student's needs. While students have had to struggle with finding consistent internet connection, handle many personal problems, adapt to staying home most of the time, and learn how to learn a language and become a teacher through independent online learning. Maison, Kurniawan, and Anggraini (2021) have described situations during the pandemic where students are becoming more independent and in charge of their own learning. Some are taking advantage of an autonomous learning environment and striving through improving their E-learning skills.

However, after teaching and learning online for two semesters, many teachers and students are learning to adapt to the new normal of E-learning in English as a foreign language (ELT) and English language teaching (ELT). Agung, Surtikanti and Quinones (2020) discussed the adaptations that have been made to a typical EFL classroom, teachers' strategies, and the student's perceptions about learning online because of the Covid-19 pandemic. Some students are even finding taking classes online is an improved learning mode for them to advance in their studies. Evisen, Akyilmaz and Torun (2020) completed a study in Turkey and found that students thought there were some advantages to E-learning during the pandemic. Some students liked having more time to complete tasks, work more independently, and ultimately many felt more comfortable learning in their own home in a safe environment. Whiles others are still struggling and feel their education is lacking because they cannot attend face-to-face classes. Evisen, Akilmaz and Torun (2020) explained many students had connection problems, many were still trying to get accustomed to the new learning process, have many distractions while studying outside of the classroom, and some just missed going to classes and socializing with other students and teachers in a face to face environment. Nartiningrum and Nugroho (2020) found similar findings in Indonesia, explaining that their students had similar challenges during the time of changing from face-to-face to online learning. This is not different in continental Africa, where Adeoye, Adanikin, and Adanikin (2020) found with the pandemic a clear divide between the poor and wealthy students in the country. Many students have not been able to afford to keep studying as education changes from a classroom setting to virtual or online education. Many students are falling behind because they do not have adequate internet access throughout the country. These advantages and disadvantages of online classes are similar to the ones that were found in Ecuador. This study found that understanding the student's perceptions of what aids in their learning and what is difficult allows for teachers to better plan their online classes and help students who do not have internet access. This contribution to the area of education will aid teachers around the world who are attempting to plan classes and teach to the needs of their students. 


\subsection{Perceptions}

When discussing students' perceptions, it is important to understand how this idea can be defined. McDonald (2011) explains how perceptions can be one's reality and how one person sees that experience. He goes onto explain how many factors such as religion, geography, cultural expectations, level of education, and personal background can all affect how a single person can perceive an event or activity taking place. Meaning most people having similar experiences can all have different perceptions. Qiong (2017) defines perception as to how people understand and internalize knowledge, experiences, or expectations. The author goes onto to explain that first, people choose what they will perceive from the world around them. Then they must construct a format that makes sense to them to understand the information being internalized. Finally, they decipher the organized information to create individual perceptions of a person, place, thing, or experience.

Perception can be manipulated and different depending on factors that affect the students. Akande and Samson (2009) go even further and explaining that a person's prior knowledge of the situation can also play a role in affecting how that person perceives the situation was occurring, especially in education. De Lange, Heilbron, and Kok (2018) make it clear that what people know before the thing or experience can shape people's perceptions about that area.

\subsection{Distance Learning, E-learning, and Face-to-Face Learning}

To understand the changes that have occurred in the past year and the effects they have had on university students, first, we must understand the different mediums that have been used in education. Radha, Mahalakshmi, Kumar and Saravanakumar (2020) explain that education is how students can learn. In turn, this is how students gain knowledge about a certain subject or area of importance. It is important to understand how learning outside of the classroom has evolved over time. Teachers had always taught in a traditional face-to-face classroom, though before the pandemic, many universities had created distance learning programs. These programs were defined by Moore and Kearsley (2012) as a way for students to obtain classroom-based instruction outside the classroom using various forms of technology, so students can receive courses while physically in a different place than in a traditional classroom. Today, students have not been given the option of being in a classroom, and therefore, physically being in a different place is the only feasible option available. Therefore, taking courses has become what Finch and Jacobs (2012) explain as distance learning or being in a different place and still allowing students to have a classroom experience. Bell and Fedeman (2013) suggest that these distance learning programs have adapted because of the egregious amounts of technological advances on the internet or worldwide web. However, it is important to point out that distance learning has rapidly evolved into an updated medium called E-learning. This can be defined by Layali and AlShlowiy (2020) as the use of all online tools such as video conferencing applications, messaging applications, and social media applications that promote interaction. These researchers go on to explain how these tools can aid in students learning and allow for mimicked social interactions that once occurred in a face-to-face classroom creating an optimal learning environment for some participants.

\subsection{Pandemic Problems and Solutions from around the World in the Area of Education}

Around the world, teachers and students have experienced many of the same struggles that have been brought about by the COVID -19 pandemic. Azzahra (2020), Agung, Surtikanti and Quinones (2020), and Nartiningrum and Nugroho (2020) describe how in Indonesia, many low-income students whose families live outside large cities do not have access to the internet or have very limited resources to be able to study online. This broadens the inequality between students even more than before the pandemic. They go onto describe how having stable internet has been a major impediment for changing to an E-learning environment. Azzahra (2020) goes onto to explain how these new problems also have come with big solutions. The government and private organizations have been working nonstop to increase access to technology for low-income students and create new forms of learning online to aid in the teaching and learning process around the country. Nartiningrum and Nugroho (2020) have shared how teachers who have experienced the problems of students not being able to connect or becoming less motivated to learn have innovated teachers to learn new teaching strategies and create powerful online learning tools. Other countries discussed by Evisen, Akyilmaz and Torun (2020) are Turkey, which has had similar problems and is working to find new solutions. Students have made it clear that they feel as though they cannot interact as well with their classmates and teachers in an E-learning mode verse a face-to-face class, according to Adnan and Anwar (2020). This 
is a common complaint and perception of students around the world. In the Philippines, Toquero (2020) mentions how curriculum adaptions are necessary for higher education to improve the learning of students. The author explains how universities and institutions were not ready for the pandemic, and changes are necessary for education to improve. Ecuador is no different. Asanov, Flores, McKenzie, Mensmann, and Schulte (2021) found that students struggle with an internet connection, and not everyone has access directly from their home or has the tools necessary to take online classes. Lynch (2020) goes even further, saying that even with the correct use of technology and access to the internet, online classes need to be adapted to the new format. Students find many teachers are not adapting the curriculum to fit the new normal. This is creating a disconnect between the virtual classes and the material.

Teachers and institutions around the world have begun to adapt to the new form of education and learning that is necessary because of the pandemic. Teachers have begun innovating their teaching strategies and utilizing technological tools to better their online classes. In India, Jena (2020) explains these are the ways the pandemic has actually created opportunities in education. Teachers have learned new tools and are applying strategies that were not used in the past. Not only are teachers adapting, but the government has invested in educational platforms to aid in student learning. In Chile, Sepulveda-Escobar, and Morrison (2020) explain how the pandemic has created an environment for new innovations and for teachers to expand their knowledge and technological abilities. This has been a huge advantage of moving to online learning in the country. Velle, Newman, Montgomery and Hyatt (2020) explain that at first, the teachers struggled with changing to online teaching, but with a push for teacher training programs for new technology and strategies to teach online virtual courses are improving. They found many teachers are taking courses to improve their technology use to gain more strategies for interactive online teaching methods. These training have been opportunities for teachers to participate in professional development courses and become better teachers. Tejedor, Cervi, Tusa and Parola (2020) found in Ecuador that students enjoyed E-learning classes when the teacher was prepared and used ICT interactive strategies for teaching. However, they explained that for many of their classes, the teachers were not prepared with these types of tools and did not have the knowledge to make classes innovative.

Another factor that was found is how fast many young students were able to adapt to virtual or online classes if they had internet access. In Greece, Kamarianos, Adamopoulou, Lambropoulos, and Stamelos (2020) found many students adapted to the new norm faster than many teachers, considering how comfortable they were with using technology. However, they found that access to new technology played a major role in their ability to adapt. Through various studies around the world, it can clearly be seen that access to technology, materials, and the internet are very important for being successful and play an important role in students' perceptions of online learning.

\section{Method}

This paper proposes the question of how students have perceived changes to EFL classes at a university level, their opinions and lived experiences about the positive and negative effects of Elearning and teaching, and students' personal life during the time of a pandemic. The objective of this research was to find out why some students prefer online learning, while others are still struggling to improve and feel comfortable taking classes in this mode to better prepare future online classes and be more prepared to teach them.

It is based on qualitative research following a phenomenological approach as it is based on how student educational lives have changed because of the pandemic and describe the pros and cons of these changes when participating in E-learning given by the students themselves. This approach allows the readers to understand how the population has felt during the pandemic and their personal experiences in virtual class situations. The research is based on an online questionnaire. This questionnaire had eight questions, and some were open-ended, and some were structured. The questions asked about students learning preferences, perceived positive and negative effects of Elearning, factors which affected their ability to learn in a positive or negative way. This allows for interpretation of the student's opinions of their experiences from changing from face-to-face to online learning during the pandemic. This paper is based on a sample of 69 upper intermediate ELT teacher trainee students from UNAE. The researcher observed virtual meetings, using answers from a semistructured questionnaire asking about students' experiences, feelings, and opinions about the changes 
that have occurred based on online learning and 15 one on one interviews of various students' personal experiences throughout the last year of their education during the pandemic in the ELT teacher training major.

\section{Findings and Discussion}

\subsection{Findings}

This paper shows students' perceptions about online learning verse face to face learning. Figure 1 explains the percentage of students that prefer virtual to face-to-face classes.

\section{Do you prefer virtual or face to face classes? \\ 47 responses}

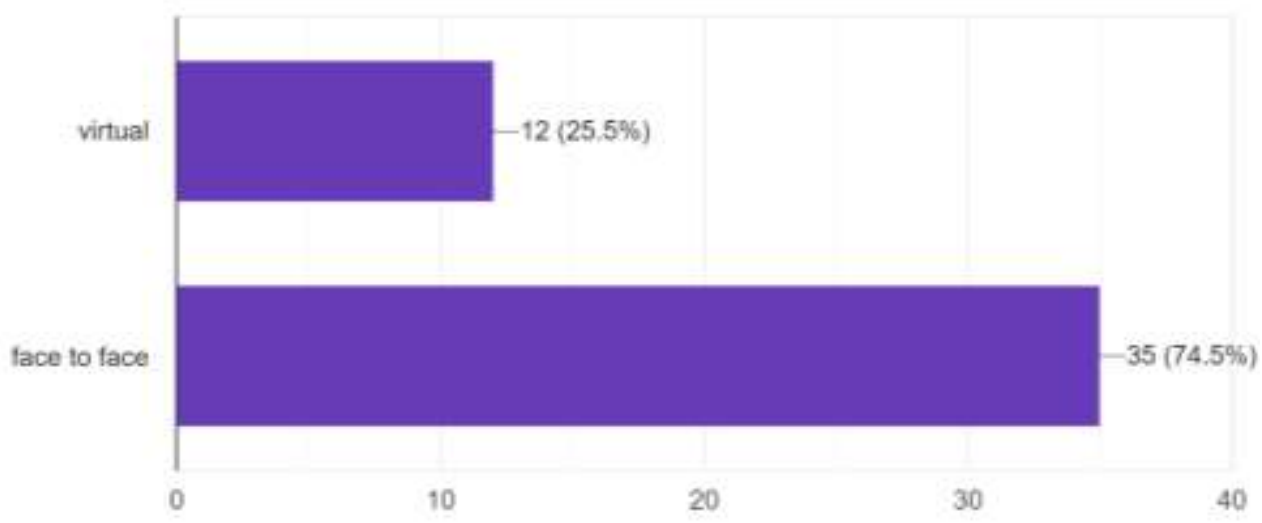

Fig. 1. Comparison of virtual to face to face classes

Figure 1 shows the number of students who prefer virtual learning to face-to-face learning. It can be seen about 70 percent of students prefer face-to-face classes, to about 30 percent of students prefer virtual learning. The mind map in Figure 2 explains why some students prefer face-to-face learning verse virtual learning.

Figure 2 shows 47 students' different reasons why they prefer taking classes face to face instead of the current virtual mode.

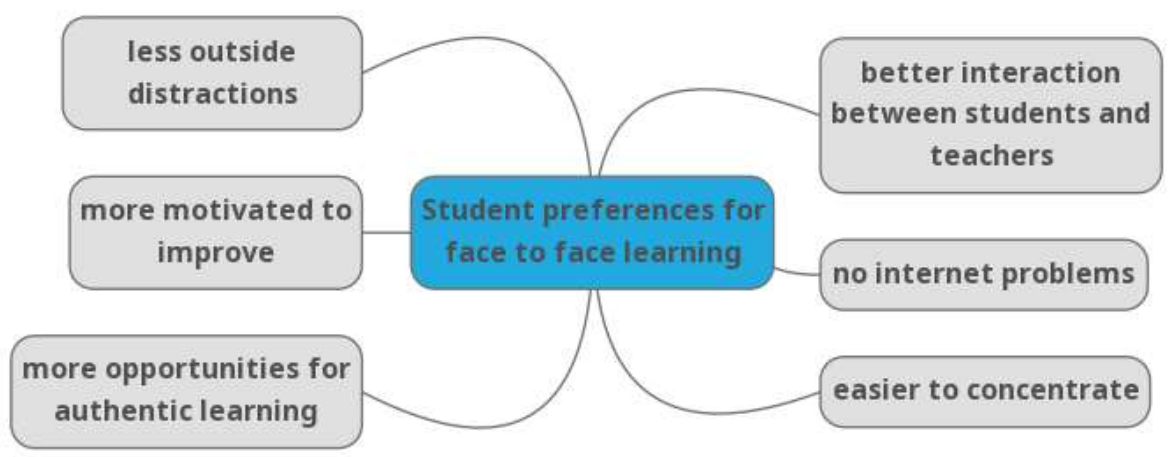

Fig. 2. Mind map of students' preference on face to face class

Figure 2 lists the reasons why 47 students prefer face-to-face learning. Thirty students explained that when studying in the classroom, they are able to concentrate better and have fewer distractions than when studying online. Forty students said that they do not have to worry about their internet connection or any technical problems. Twenty students explained that they have more opportunities 
for real interactions in English, such as spontaneous conversations with their teachers and peers. Fifteen students made it clear that they can interact more with their peers, and they can ask questions to their teachers when they need to.

Figure 3 shows 22 students' reasons as to why taking classes virtually aids in the learning process.

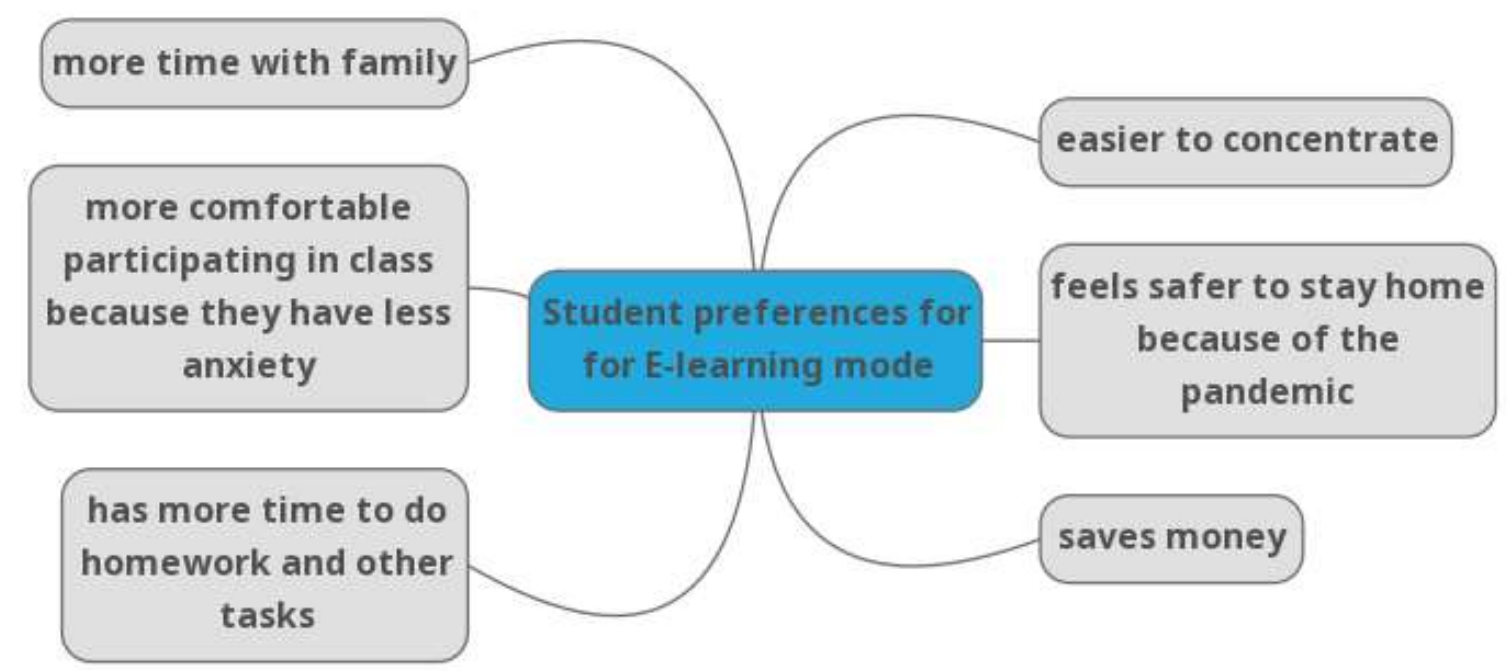

Fig. 3. Mind map of students' preference on virtual class

Figure 3 identifies the reasons why 22 students prefer virtual or an E-learning mode to face-to-face classes. Eighteen students explained that they now have more time to spend with their family and to complete tasks and responsibilities at home. Ten students described how when they were attending university, they used to spend more money on food and transportation, and now they can save this money. Seven students found it is much easier for them to concentrate in class while learning virtually. They have found they are less distracted while staying home to learn. Twenty students feel safer at home because of the Coronavirus and are happy they are not exposed to getting sick. Ten students have less anxiety and find themselves participating more in English virtually. They expressed they are less embarrassed if they answer incorrectly while studying behind a screen.

\subsection{Discussion}

The research began with twenty class observations of intermediate English language classes online over the course of one semester or four months. These observations gave important information about factors that can show how well virtual classes are functioning, such as how students participate in class, general types of questions they had, and difficulties students had while attending these classes. It is important to understand students' perceptions. Qiong (2017) explains how perceptions can help understand a person's situation, and this can aid the teacher in creating a better learning environment for the students.

In every class observation, 60-90\% of the students did not turn on their video cameras for the entire class, while only about $50 \%$ of the students actively participated in a class by sharing answers and asking pertinent questions connected to the class content. When asked about why they did not turn on their videos in the one-on-one interviews, many students explained that they either did not have a working video, their internet connection was not good enough to allow them to turn on their video, or they were doing other activities while attending class and therefore could not turn them on. Just as Kamarianos, Adamopoulou, Lambropoulos, and Stamelos (2020) found, students can participate and increase their abilities to learn when technology and internet connection are not a problem.

One student said:

"I do not have a computer, and we do not have the internet at home. I have to use my cell phone for class and use the internet from my cell phone provider. I simply do not have enough internet to turn on my camera.", 
In the questionnaire, students explained that they did not turn on their video cameras and sometimes did not participate in class because they were worried about their appearance, they were working, cooking a meal, taking care of their younger siblings or their children, or felt uncomfortable turning the camera on. Many explained they did not participate because they were embarrassed, felt they did not know the right answers, would say the wrong thing, or we're doing other activities while signed into class.

One student explained that she is home with her younger siblings and baby and must help her siblings in their online classes, take care of her baby and attend class at the same time. She is doing her best to pay attention in class but cannot actively participate or turn on her camera for the aforementioned reasons.

Because of the pandemic, many students have needed to get a job to help their families financially. One student commented:

"I now have to work to provide for my child since my husband lost his job. I am working while I am attending your class, and this is the reason I cannot turn on my camera."

The reasons mentioned above were observed in the virtual classes, and when asked in the questionnaire if students prefer face to face classes or E-learning, they said they prefer going to class because they are distracted at home and cannot focus or pay attention like when they were in classes in the university.

One student described how when she could attend class in UNAE she could focus only on her studies and not taking care of her family and going to work at the same time. This gave her the ability to study more and learn more in her classes.

Many students all agreed the most difficult aspect of E-learning is having a stable internet connection and the use of a computer for classes. Many students described how they share one computer with their siblings or must take classes on their cellphones. There are a few who do not have stable internet access in their homes and have had to go to a public area with free internet.

One student said:

"At least once a week, the internet in my house does not work, and I must put myself in danger of getting the virus (COVID) by taking a bus to the city center and find free Wi-Fi to take my classes."

On the other hand, there were some students who said they have found they prefer taking classes online and not having to go to the university each day. Some students explained that they live extremely far from the university and now they have more time for homework, their personal life, and studying because they do not have to travel more than two hours each day.

Ten students described how they feel more comfortable and participate more through zoom classes than they did when they attended classes face to face. They explained how they have found they learn better independently and have more confidence actively participating in class from behind a screen. These students voiced that they are improving and learning much easier since beginning classes in an online format. Students have found when teachers have adapted the curriculum and use new technological tools. They find online learning easier for them. Tejedor, Cervi, Tusa and Parola (2020) found that in Ecuador, teachers' knowledge of technology and how they adapted their classes changed the perceptions of the students who were learning online to a more positive perspective.

The results of the findings have shown that many of sixty-nine students from the English language teaching major from semesters four, five, and six have various feelings about studying online and face to face. Forty-seven students explained that they prefer learning in a face-to-face classroom, while twenty-two students find E-learning a better format for their individual needs.

Twenty-two students who said they preferred face-to-face classes had various reasons. Twenty students explained they have internet connection problems, platform problems, and general technology issues, which make studying online more difficult for them. Eleven students explained they have more opportunities to improve their oral and listening English language skills and have better interaction with the teachers and other students for the purposes of studying understanding topics, and asking questions while attending face-to-face classes. Nine students said they could not 
focus at home and have many distractions when taking synchronous classes, and trying to study at home can be a very difficult task. These findings explain why many students prefer learning in a faceto-face setting instead of online learning.

However, there were twenty-two students who have adapted to E-learning and have come to prefer taking classes online. Ten students explained that they feel more relaxed at home because of the pandemic and do not have to worry about getting sick. Nine students said they have found that learning from the comfort of their home has made them feel more relaxed and less anxious about speaking in front of others in the class. They have found they participate more in class because they are behind a screen and do not feel like the spotlight is on them, and they are saving a lot of time and money because they do not have to travel to the university. This has allowed them to have more time for homework, studying, working, and for their families.

\section{Conclusion}

Before the pandemic, technology was being used in classrooms and advancing at a rapid rate, these changes in technology have changed the way students learn, and teachers teach. Then the pandemic began, and this research found students have different opinions about learning face to face verse Elearning. Most students would like to go back to face-to-face classes as soon as possible for many different reasons. However, some students have found learning online to be beneficial to their individual learning styles and needs. Since converting to E-learning was so difficult for most, finding out that some students are more comfortable and learning more comes. This research has proven to be interesting since it shows how students learn and improve in different ways depending on their individual needs and living conditions. This paper also found that there are many uncontrollable outside factors in each students' life that can affect their ability and interest to learn in an online mode.

The implications of this research shows how technology can affect teaching and learning. It also explains how students perceive this use of technology, which in turn can influence the teacher's abilities to teach effectively. Without stable internet access, all of the planning and creation of online courses for students can be deemed useless since the students cannot participate properly. Students made it clear that without this, assisting classes online is almost impossible and demotivating. They had also expressed that having many other responsibilities in life such as a job, a family, children, and siblings make studying at home not as important as when they were able to study in a classroom. This can implicate that many students need more support financially and personally to strive and learn in an online setting verse a face-to-face classroom setting since students who have these types of support tend to enjoy online learning more, and some students enjoy this new mode of learning at the university level in Ecuador.

Author contribution : The author confirms sole responsibility for the following: study conception and design, data collection, analysis and interpretation of results, and manuscript.

Funding statement $\quad:$ The research is funded under no research project.

Conflict of interest $\quad$ : The author declares no conflict of interest.

Additional information : No additional information is available for this paper.

\section{REFERENCES}

Adnan, M., \& Anwar, K. (2020). Online learning amid the COVID-19 pandemic: Students' perspectives. Journal of Pedagogical Sociology and Psychology,2(1), 45-51. doi.org/10.33902/JPSP.\%202020261309

Adeoye, I. A., Adanikin, A. F., \& Adanikin, A. (2020). COVID-19 and e-learning: Nigeria tertiary education system experience. International Journal of Research and Innovation in Applied Science, 5(5), 28-31. Retrieved from https://www.researchgate.net 
Agung, A. S. N., Surtikanti, M. W., \& Quinones, C. A. (2020). Students' perception of online learning during COVID-19 pandemic: A case study on the English students of STKIP

Akande, Samson O. (2009). Knowledge, perception, and attitudes of library personnel towards preservation of information resources in Nigerian Federal University libraries. Library and Phylosophy Practice eJournal. 303. Retrieved from http://digitalcommons.unl.edu/libphilprac/303/

Asanov, I., Flores, F., McKenzie, D., Mensmann, M., \& Schulte, M. (2021). Remote-learning, time-use, and mental health of Ecuadorian high-school students during the COVID-19 quarantine. World development, 138, 105225. Retrieved from https://www.ncbi.nlm.nih.gov/pmc/articles/PMC7581322/

Azzahra, Nadia F. (2020). Addressing distance learning barriers in Indonesia amid the Covid-19 pandemic. Center for Indonesian Policy Studies. doi:10.35497/309162

Bell, B. S., \& Fedeman, J. E. (2013). E-learning in postsecondary education. The Future of Children, 23(1), 165-185. Retrieved from https://www.researchgate.net

Cabero, J. (2006). Bases pedagógicas del e-learning. Revista de Universidad y Sociedad del Conocimiento, 3(1), 1-10. Retrieved from http://www.uoc.edu/rusc/3/1/dt/esp/cabero.pdf

Constante, S. (2020). Ecuador: la educación online desde casa es imposible e injusta. El Pais. Retrieved from https://elpais.com/elpais/2020/06/12/planeta_futuro/1591955314_376413.html

De Lange, F. P., Heilbron, M., \& Kok, P. (2018). How do expectations shape perception? Trends in cognitive sciences, 22(9), 764-779. doi.org/10.1016/j.tics.2018.06.002

Evişen, N, Akyılmaz, Ö, Torun, Y. (2020). A case study of university EFL preparatory class students' attitudes towards online learning during Covid-19 in Turkey. Gaziantep Üniversitesi Ĕgitim Bilimleri Dergisi, 4(2), 73-93. Retrieved from https://dergipark.org.tr/en/pub/guebd/issue/59201/803017

Finch, D., \& Jacobs, K. (2012). Online education: Best practices to promote learning.Proceedings of the Human Factors and Ergonomics 56th Annual Meeting. doi/abs/10.1177/1071181312561114

Allo, M. D. G. (2020). Is the online learning good in the midst of Covid-19 Pandemic? The case of EFL learners. Jurnal Sinestesia, 10(1), 1-10. $\quad$ Retrieved from https://sinestesia.pustaka.my.id/journal/article/view/24

Jena, P. K. (2020). Impact of pandemic COVID-19 on education in India. International Journal of Current Research (IJCR), 12. doi.org/10.24941/ijcr.39209.07.2020

Kamarianos, I., Adamopoulou, A., Lambropoulos, H., \& Stamelos, G. (2020). Towards an understanding of university students' response in times of pandemic crisis (covid-19). European Journal of Education Studies, 7(7). doi.org/10.46827/ejes.v7i7.3149

El Universo. (2020). La educación en Ecuador tiene que continuar y todos debemos apoyarla, asegura Unicef. Retrieved from https://www.eluniverso.com/noticias/2020/08/26/nota/7955776/educacion-tiene-quecontinuar-todos-debemos-apoyarla/

Layali, K., \& Al-Shlowiy, A. (2020). Students' perceptions of e-learning for ESL/EFL in Saudi universities at time of coronavirus: A literature review. Indonesian EFL Journal, 6(2), 97- 108. doi: 10.25134/ieflj.v6i2.3378

Lynch, M. (2020). E-learning during a global pandemic. Asian Journal of Distance Education, 15(1), 189195. Retrieved from http://www.asianjde.org/ojs/index.php/AsianJDE/article/view/457

Maison, M., Kurniawan, D. A., \& Anggraini, L. (2021). Perception, attitude, and studentawareness in working on online tasks during the covid-19 pandemic. Jurnal Pendidikan Sains Indonesia (Indonesian Journal of Science Education), 9(1), 108-118. Retrieved from http://erepository.unsyiah.ac.id/JPSI/article/view/18039

McDonald, S. M. (2011). Perception: A concept analysis. International Journal of Nursing Terminologies and Classifications, no-no. doi.org/10.1111/j.1744-618X.2011.01198.x

Moore, M., \& Kearsley, G. (2012). Distance education: A systems view of online learning (3rd ed.). Belmont, CA: Wadsworth. doi.org/10.1080/00131911.2020.1766204 
Nartiningrum, N., \& Nugroho, A. (2020). Online learning amidst global pandemic: EFL students' challenges, suggestions, and needed materials. English Franca: Academic Journal of English Language and Education, 4(2), 115-140. http://dx.doi.org/10.29240/ef.v4i2.1494

Qiong, O. U. (2017). A brief introduction to perception. Studies in Literature and Language, 15(4), 18-28. Retrieved from http://flr-journal.org/index.php/sll/article/view/10055

Radha, R., Mahalakshmi, K., Kumar, V. S., \& Saravanakumar, A. R. (2020). E-Learning during lockdown of Covid-19 pandemic: A global perspective. International journal of control and automation, 13(4), 10881099. Retrieved from http://sersc.org/journals/index.php/IJCA/article/view/26035

Raveendran, B. (2021). Lessons on learning: How the pandemic changed education. Forbes India. Retrieved from https://www.forbesindia.com/blog/education/lessons-on-learning-how-the-pandemic-changededucation/

Sepulveda-Escobar, P., \& Morrison, A. (2020). Online teaching placement during the COVID-19 pandemic in Chile: Challenges and opportunities. European Journal of Teacher Education,43(4), 587-607. doi.org/10.1080/02619768.2020.1820981

Sun, A., \& Chen, X. (2016). Online education and its effective practice: A research review. Journal of Information Technology Education: Research, 157-190. Retrieved from https://www.researchgate.net/publication/310503884_Online_Education_and_Its_Effective_Practice_A_ Research_Review

Tejedor, S., Cervi, L., Tusa, F., \& Parola, A. (2020). Education in times of pandemic: Reflections of students and teachers on virtual university education in Spain, Italy, and Ecuador. Revista Latina de Comunicación Social, (78), 1-21. doi:10.4185/RLCS-2020-1466

Toquero, C. M. (2020). Challenges and opportunities for higher education amid the COVID-19 pandemic: The Philippine context. Pedagogical Research, 5(4).doi.org/10.29333/pr/7947

Velle, L. L., Newman, S., Montgomery, C., \& Hyatt, D. (2020). Initial teacher education in England and the Covid-19 pandemic: Challenges and opportunities. Journal of Education for Teaching, 46(4), 596-608. doi.org/10.1080/02607476.2020.1803051 